\title{
THE SQUAW CREEK SAGA
}

\section{STUART HOUSTON, 863 University Drive, Saskatoon, Saskatchewan. S7N $0 J 8$}

In the early 1980s a pair of Ospreys used a dead spruce, unsafe for humans to climb, near the south edge of the muskeg at Squaw Creek, which empties into Upper Makwa Lake. Fearing that the tree was about to fall, we chopped it down in March 1985. We built a replacement platform in a tamarack chopped off 26 feet from the ground, nicely hidden by a thin rim of spruce trees beside Highway 699, between Loon Lake and Ministikwan Lake.

That summer the Ospreys raised three young, banded on 13 July. In 1986, Frank Scott sighted an Osprey sitting on the platform on 18 April, his earliest spring date. One young fledged, leaving an unhatched addled egg in the nest. In 1987 two young were banded. In 1988 we captured and banded the adult female on her nest, using a temporary noose carpet over her four eggs. Unfortunately that July the $3 / 8$ inch lag bolts broke, the platform collapsed in a heavy windstorm and the young perished on the ground. The adults at once began building a new nest in a dead spruce several hundred yards out in the muskeg.

In March 1989 we constructed a new platform in a spruce, 34 feet above the ground. The Ospreys occupied their new platform, where we again trapped the adult female in early June and banded two young on 15 July.

On 2 June 1990 we trapped the banded adult female for the third time. This was the year of the lowest productivity yet encountered near Loon Lake, both for nests on platforms and in live trees. This nesting attempt was among the many failures.

In 1991 the Ospreys moved to the nest in the unsafe dead spruce stub, 35 feet above the ground. What a pity. We could not band the three young. Even without them we tied our best-ever year, banding 29 nestlings.

Worried that the dead snag might blow over in a windstorm and kill the precious young, we recalled the 1989 feat of the indefatigable Nigel Mathews. Nigel had masterminded the erection of our first successful windmill platform in another muskeg south of the old railway grade where there was no tree in which to build a substitute platform. We asked Lawrence Beckie at Bladworth to look for another available windmill frame. The first farmer he contacted vacillated but then decided that he needed his unused windmill as a lookout to keep track of his cattle. Several other leads failed before Lawrence phoned again.

Harry's Trailer Rental, used by Nigel in 1989, provided a 16-foot trailer. On 19 July, Frank Scott, Dr. Carl Torbiak and Bernice Little joined my wife, Mary, and me. Alf Davis, Frank Scott's father-in-law, was willing to prefabricate the platform at 
their acreage south of Saskatoon over the weekend, so that Kelly Wylie, David Miller, Frank Scott and Larry Chambers could transport it to Loon Lake on 22 July. We trundled the trailer down 70 miles, only to find that the windmill was broken and twisted on top and was out in the middle of an excellent crop. A superb windmill nearer Bladworth was also out in crop and we later learned the owner wished to prepare it as a future heritage exhibit. When we got back empty-handed at midnight, Harry Sakundiak generously charged us nothing for the trailer rental.

I phoned the wife of a friend who had once donated his old climbing spurs we still use. Her brother, retired from farming, had two non-functioning windmills near Bladworth. She tentatively promised me the windmill in the pasture, thinking he would like to keep the windmill in the yard for sentimental reasons. He decided the farm would not look right without two windmill frames.

On 20 July we placed a request in Heather Robertsons's column in the Saskatoon Star-Phoenix and three days later I went on Carol Blenkin's television show on CFQC-TV and on CFQC radio news. I told how immediate erection of a windmill might save two years production of this Osprey pair: this year's if a storm came along and next year's because it would take them a year to build a new nest. I got a response from Bob Robinson, a regular owl nest finder. Bob had sold a windmill to me for $\$ 50$ three years earlier. It was still dismantled. The new owner agreed to sell it back for $\$ 50$. On 24 July we rented the trailer again and made an evening journey of $90 \mathrm{mi}$. each way to just the other side of Prince Albert. Bob Robinson and Kelly Wylie, a former banding helper visiting from Ot- tawa, went with us. We loaded up the windmill pieces and got home at 1:00 a.m.

Kelly, with Dr. Johann Kriegler, took the windmill on the trailer to Loon Lake on 25 July; they were joined there by Larry Chambers and Frank Scott. In Loon Lake village they drilled the holes in the lumber and the windmill frame. Larry Chambers brought his three-wheel all-terrain vehicle from Peck Lake, but it would not pull the windmill frame. The four men carried the lighter upper half of the windmill to the base of the birds' stub, with guy wires and other gear. They simply were not strong enough to carry the heavier lower half, and had to leave the area since they did not wish to disturb the Ospreys for more than an hour at a time. They had made a good trail from Highway 699 through the willows to the base of the nest stub, through spongy muskeg.

On 5 August, we set out early with John Hanbidge, David Miller, Dylan von Kuster and Dr. Jennie Lee in my vehicle and Dr. Johann Kriegler and Dr. Phil Browne, his wife Ann and son Brendan, in the other. The oldest Osprey nestling was now flying well. The second was perched on a nearby tree, but took off at our approach and flew in circles for $20 \mathrm{~min}$ utes. The youngest nestling remained on the nest. One of the adults carried both an aluminum band on the right leg and a blue band on the left.

After dragging the lower half of the windmill frame to the site, we put the two parts together and bolted on the pre-drilled wooden two-by-sixes, then with ropes pulled the frame erect, stabilizing it with four guy wires, ornamented with coloured tennis balls to warn any birds or aircraft 


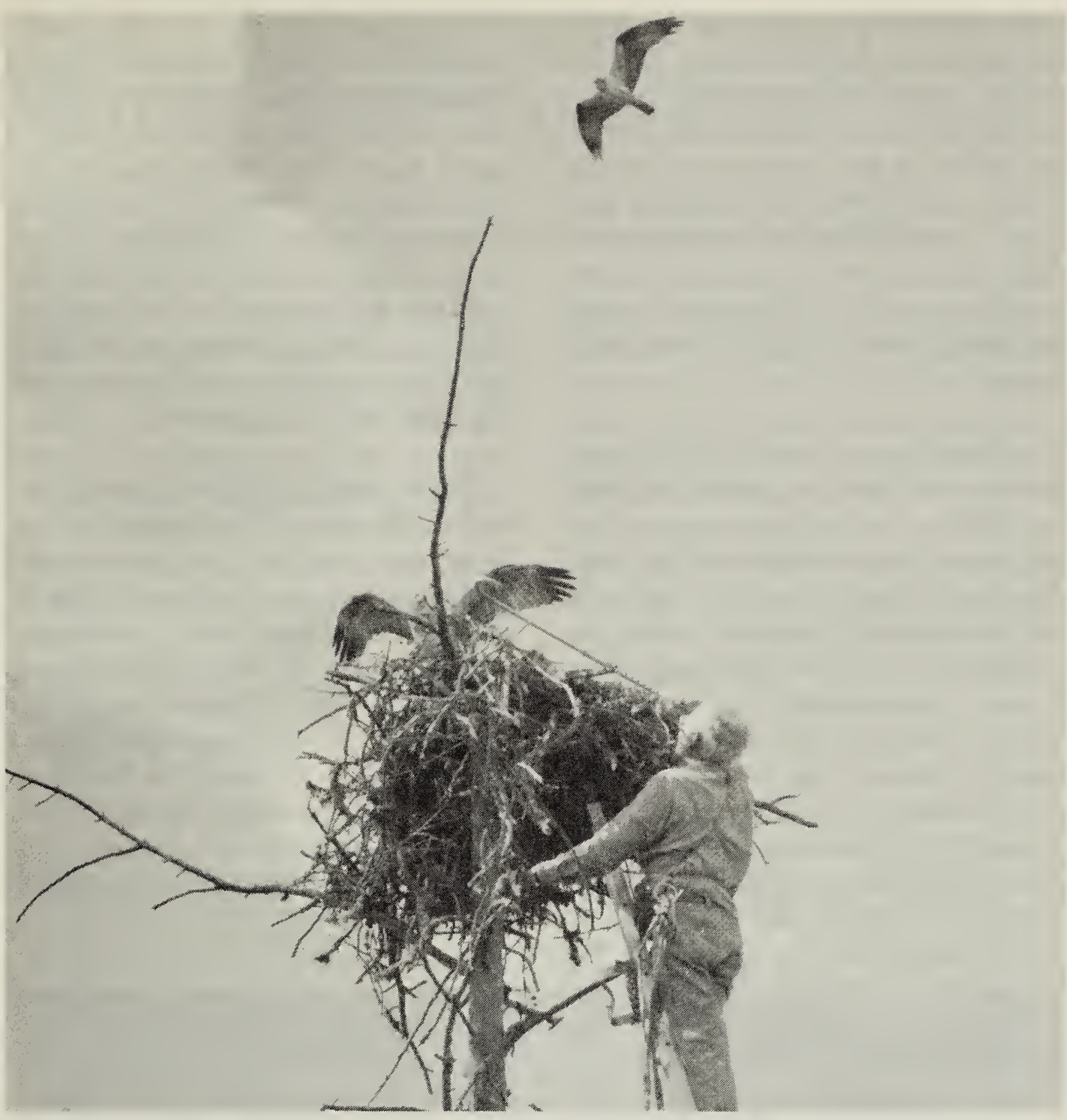

A frightened Osprey bander. The ladder does not touch the tree or the nest

Phil Browne

flying by.

Was there any chance of banding the remaining young Osprey? I calculated that if we tied our two 10-foot sections of aluminum ladder high on the windmill frame, that it might be possible to reach the young Osprey - or miss reaching it by about one foot. We joined the two 10-foot sections with cleats, then Johann and David roped the lowest 8 feet of the aluminum ladder to the windmill frame. The top 12 feet extended into the air, almost to the bottom of the giant nest.
The 10 or 12 degrees sideways slope of the windmill ladder was both good and bad news. Unlike our previous windmill frame which had a built-in vertical ladder, this windmill's ladder tilted along the margin of the windmill that becomes narrower and narrower as it goes up. Did you ever try walking up 12 feet of slanting ladder into empty space, towards a giant nest in a totally rotten tree, leaning far to the left to keep vertical and not tilt the ladder even farther? However, had the ladder not tilted, it would not have put me within reach of the nest. John Hanbidge sat at the top of the frame, 24 feet up, with the 
rope holding the ladder anchored to his waist, holding the ladder with his strong arms. ("Hercules Hanbidge," our friend Silvia Gerard calls him; in his youth he was second in Canada in his weight class as a wrestler and won a provincial championship this year against much younger opponents.) I would not have dared climb the ladder without John's strength to steady it.

I climbed the windmill's ladder and then up our roped-on ladder to below the bottom of the Osprey nest. The spruce was so obviously rotten that I dared not touch it. Directed by those on the ground, I reached over the nest with a stick and felt the nestling. It was very strong; it would not budge. I broke off two sticks from the edge of the nest so I could see the young Osprey. My cane was sent up on a string. Scared stiff and perspiring, I reluctantly and timidly went one rung higher than I felt safe. Scooping the Osprey with the curve of the cane, I grasped the legs of a very healthy and fully feathered young Osprey which then flapped its wings furiously, as if trying to carry me off. I came down four steps, shaking the whole ladder. Those on the ground could hear my knees knocking. I put an aluminum band on the left leg, riveted the colour band on the right leg, climbed back up, retrieved my cane from the top of the nest, and put the Osprey back. Fait accompli.

On 15 March 1992 we returned to Squaw Creek and chopped down the dead tree, which to our amazement had withstood the wind in spite of its extremely rotten and weakened structure. We nailed the planks on top to complete the platform, before moving the contents of the 1991 nest structure onto the windmill frame. In future it will be easier to climb and band the Ospreys. I am too old to repeat another escapade up a ropedon sloping ladder.

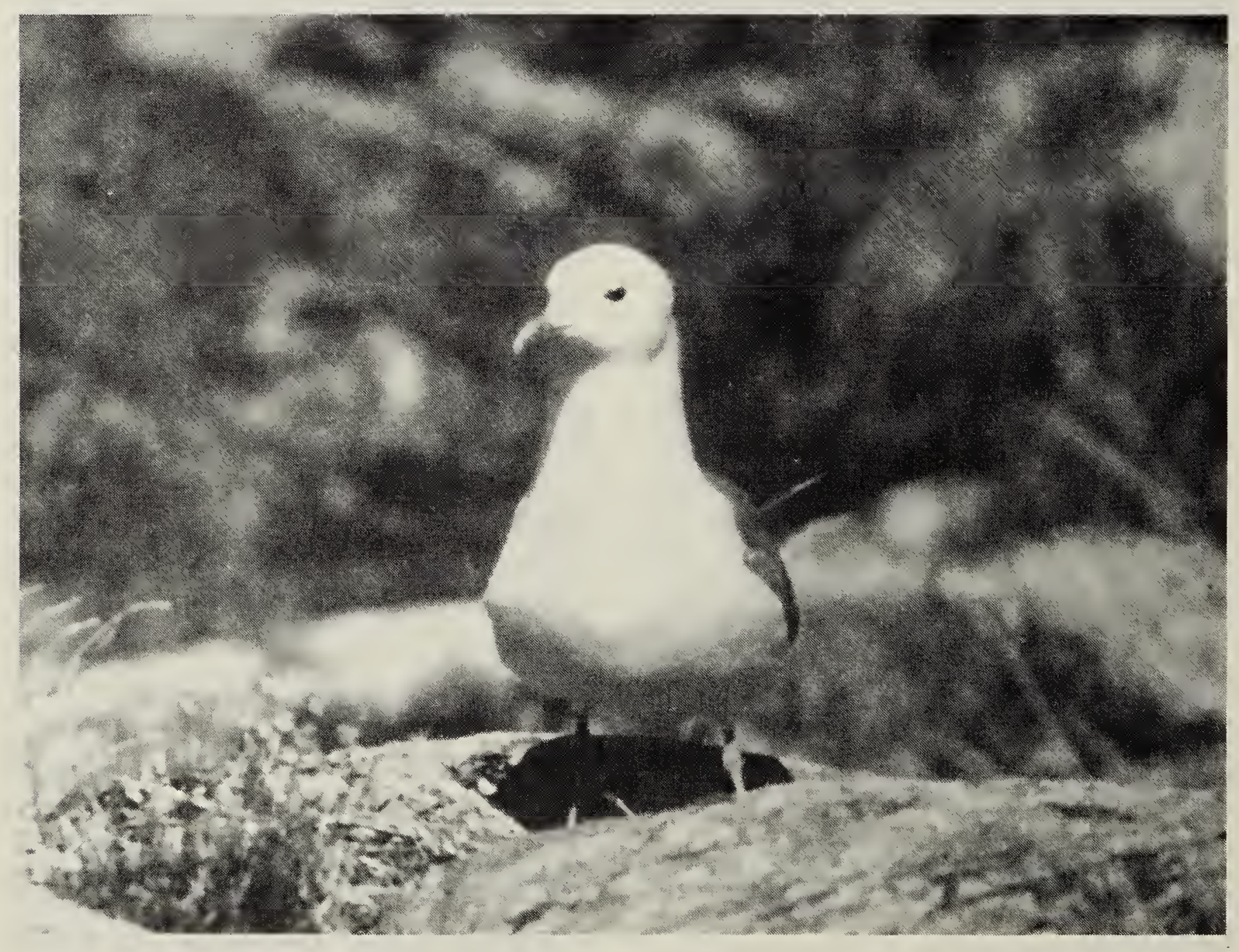

